\title{
The Impacts of COVID-19 on China's Food-Service Industry
}

\section{-- Based on the Case Study of Haidilao Hot Pot}

\author{
Bodi Zhang ${ }^{1, *}$ \\ ${ }^{1}$ School of Public Affairs, Chongqing University, Chongqing, China, 400044 \\ *Corresponding author. Email: janezhang201105@163.com
}

\begin{abstract}
As a worldwide disaster, the COVID-19 challenges every aspect of China's economy. Although the situation has got controlled in China currently, it seems that it is still hard for people and companies to recover back to the normal. Since China's food-service industry suffered a huge loss during the pandemic, this paper analyzes how COVID-19 impacts food-service enterprises by analyzing consumer behaviors and conducting case study of Haidilao hot pot from three dimensions: profits, supply-chain and cash flow. This study also offers suggestions based on how Haidilao reacts to the impact. The insight analysis of this case can provide references to other enterprises of food-service industry.
\end{abstract}

Keywords: COVID-19, Food-service industry, Haidilao

\section{INTRODUCTION}

COVID-19 strikes China at the end of 2019, which brings a serious and lasting challenge to every aspect of China's economy, especially to the food-service industry. In terms of its high mobility and density of population, the food-service industry suffers a huge and irreversible loss.

"Food is the paramount necessity of people." is an old Chinese saying. Eating is a vital component of the culture and lifestyle of Chinese people. Chinese economic growth reaches a world-famous achievement and the devotion of food-service industry cannot be ignored. According to National Bureau of Statistics of China, the output value of China's food-service industry accounted for $4.7 \%$ of GDP in the past five years. Meanwhile, the total income of China's food-service industry is about 467 millions, which is up $9.4 \%$ year on year, about $3 \%$ higher than China's GDP growth. As the poverty alleviation ends in 2020, to recover from Covid-19 and to find a new increase in economic growth, it is necessary and significant to analyze the influence of Covid-19 on China's food-service industry.

In terms of the report released by China Cuisine Association, compared to 2019 Spring Festival, the income of $78 \%$ of catering enterprises decreases over $100 \%, 9 \%$ of companies decrease over $90 \%, 7 \%$ of corporations decrease $70 \%-90 \%$ and only $5 \%$ companies reporting that their decrease is under 70\%.[1] However, except for the deficits, Covid-19 also harms supply chains and cash flow. Furthermore, it both affects Chinese customers preference and psychology.

\section{THE INFLUENCE OF COVID-19 ON CHINESE FOOD-SERVICE INDUSTRY --.--- TAKE HAIDILAO HOT POT AS AN EXAMPLE}

\subsection{Brief Introduction of Company}

Haidilao is a private enterprise operating hot pot. Since it firstly opened in 1994, it has grown to be an enterprise owned in 41 cities across China and currently occupies a huge share of Chinese hot pot market. Until June 30, 2020, Haidilao has owned 935 branches around the world, 868 of which are located in 164 cities of China, and 67 in Hongkong, Macao, Taiwan and overseas, including Singapore, South Korea, Japan, the United States, Canada, UK, Vietnam, Malaysia, Indonesia and Australia.

(The development history of the company is below.) 
Table 1. The annual development history of Haidilao hot pot

\begin{tabular}{ll}
\hline Year & The development history of Haidilao hot pot \\
\hline 1994 & The first Haidilao hot pot opened in Jianyang, Sichuan province. \\
$1999-2006$ & Construct branches in Xian, Zhengzhou, Beijing, Chengdu and Shanghai. \\
2007 & Complete the trademark registration in Hong Kong, Macao and Taiwan. \\
2012 & Open the first overseas Haidilao hot pot in Singapore. \\
2013 & Soft opening in Los Angelas, US. \\
2018 & Haidilao(06862) is listed on the Hong Kong Stock Exchange. \\
\hline
\end{tabular}

\subsection{The Influence of Covid-19 on Profits}

Spring Festival is a golden period for China's foodservice industry every year in terms of the extreme demand for family dinner parties. It is reported that the revenue of China's catering industry reaches 4,672.1 billion yuan in 2019, and 15.5 percent of which is from the Spring Festival. However, to retrieve the loss, most catering enterprises choose to shut down entirely, including stopping the delivery service in 2020.[2] According to the statistics released by China Cuisine Association, the Covid-19 has brought about 500 billion yuan loss just during Chinese New Year. Because the decrease in the frequency of eating outside and the cost in food storage, stuff, rent and others, the profit have plummeted drastically.

Because the hot pot belongs to the "heavy" type of food due to its form and is usually with gathering and socializing characters, it is difficult to develop delivery service. Although Haidilao's takeout service used to be one of his specialty services, it came with high costs and was unsuitable during the epidemic. As the pandemic spreads rapidly, Haidilao suspends all of its restaurants in China mainland on January 25, 2020, which makes itself suffer a huge loss. According to the financial statement released by the company, the operating revenue in the first half of 2020 was 9.761 billion yuan, with a loss about 965 million yuan.

Table 2. The income and net margin of Haidilao from 2015 to 2020.

\begin{tabular}{l|l|l|l|l|l|l|l|l}
\hline Year & $2020 / 6 / 30$ & $2019 / 12 / 31$ & $2019 / 6 / 30$ & $2018 / 12 / 31$ & $2018 / 6 / 30$ & $2017 / 12 / 31$ & $2017 / 6 / 30$ & $2016 / 12 / 31$ \\
\hline $\begin{array}{l}\text { Income } \\
\text { (billions/yuan) }\end{array}$ & 9.761 & 26.56 & 11.7 & 16.97 & 7.34 & $2015 / 12 / 31$ \\
\hline $\begin{array}{l}\text { Net margin } \\
\text { (billions/yuan) }\end{array}$ & -0.97 & 2.35 & 0.91 & 1.65 & 0.64 & 4.76 & 7.81 \\
\hline
\end{tabular}

\subsection{The Influence of Covid-19 on Supply Chain}

From the supply-chain perspective, the whole foodservice industry consists of three elements: the upstream is food suppliers, the middle is supply chain enterprises and the downstream is restaurants of all kinds of catering enterprises. Cancelled orders from catering enterprises, large amount of stock before Spring Festival, the delay of returning to work and the lock down of different region all make links of the whole chain exists obstacles.[2] Especially, after the package of some products such as frozen seafood are tested the virus in the later period of the pandemic, issues like food quality, safety and traceability challenges the recovery of supply chain of China's catering industry.
Although Hidilao hot pot has its own supply chain and cooperative upstream companies, it is still unavoidably affected by the pandemic in terms of the analysis above. Compared with other companies, it is just affected less.

\subsection{The Influence of Covid-19 on Cash Flow}

It is drastically difficult for food-service companies to get loans from banks in terms of lacking enough guaranty.

Light asset is one of typical characteristics of catering enterprises. Therefore, there are usually few fixed assets of high value which can be mortgaged inside the enterprise. Moreover, the movable asset such as food ingredients and inventories are easy to be consumed, which does not meet the mortgage requirements. When facing the epidemic, catering enterprises have limited 
channels to raise funds.[3] Through surveys, Meituan Research Institute finds that the capital of $26.8 \%$ catering enterprises has tied up, $22.9 \%$ says that they can insist for 3-4 months and $37 \%$ is extremely urgent that they can only maintain for about 1-2 months.[2]

Rising prices also put pressure on the operation. During the pandemic, the CPI of China has a obvious fluctuate. According to the statistics released by National Bureau of Statistics of China, compared to April 2020, the CPI has risen by $3.3 \%$.

Except for the increasing cost of food ingredients, staff costs always account for the largest part in expenses of Haidialao. According to 2019 financial statement, Hidilao spends almost $\$ 8$ billion on staff, which accounts for more than 30 percent of its total revenue, up 0.5 percentage points from a year earlier. Meanwhile, in the first of 2020, 4.07 billion yuan, which is about $42 \%$ of its revenue, is spent on staff expenses. As Haidilao expands rapidly, more staff are recruited. The cash flow has exhibited potential risk from 2015-2018.[4] During the pandemic, Haidilao pays the employees as usual, which puts a huge strain on its cash flow.

\section{THE INFLUENCE OF COVID-19 ON CONSUMERS' BEHAVIOR}

\subsection{Consumer Preference}

After learning lessons of SARS and COVID-19, it is estimated that Chinese consumers will mainly focus on the safety and quality of foods.[5] Additionally, in the middle and late period of the domestic epidemic, with the global outbreak of COVID-19, many imported coldchain food products are detected with corona-virus, which appeals the attention of public to the traceability, safety and hygiene of food ingredients.

Besides, as social economy develops rapidly these years, people live in a fast-pace lifestyle, which gives rise to the food-delivery industry. Small but nice restaurants with simple and healthy dishes satisfy consumers' demand for takeaway better.[5] Although the willingness of consumers to food delivery is highly related to the degree of epidemic prevention and control since there are widespread cases of infection caused by food delivery workers, there is still an impressive recover of food delivery service after epidemic getting controlled.

The Covid-19 quarantine can be regarded as a forced experiment. By long time staying at home, people's behaviors are gradually changed. It is expected that the pandemic strengthen people's reliance on delivery service. And Yuan, Li and Wang surely find that the tendency of willingness to food delivery is mounting during and after the pandemic.[6]

During the quarantine, simple and light dishes are more popular. In terms of the survey conducted by Yuan,
$\mathrm{Li}$ and Wang, there are 76.36 percent of consumers prefer to order convenient and delicious processed foods and 31.83 percent of people choose semi-finished food products during the pandemic.[6]

Therefore, it can be foresaw catering enterprises that standardized and specialized restaurants will be predominate in the market. And food safety, hygiene and traceability will gradually become new hot points of foodservice industry.

\subsection{Consumer psychology}

Due to the unpredictable risk brought by the Covid19, Chinese consumer psychology is affected.

Although the control of pandemic in China goes well and the affect of Covid-19 on the income is limited, there is still 45 percent people reporting that they suffer an income decrease.[6] Therefore, consumers will hold a more negative attitude towards the future, which may result in the precautionary saving motivation due to the expectation to an income reduction.[7] Otherwise, such change will lead consumers pay more attention to the price.

Besides, in the panic buying scale built by Lins and Aquino, they find that impulse buying happens more when facing the fear. During the COVID-19, people buy more products during the Covid-19,[8] which is proved by the research conducted by Yuan, Li and Wang that people do spend more on purchasing daily supplies.[6]

Also, as people have to stay at home to be selfquarantine during the epidemic, activities such as working, shopping and education have to turns from offline to online. Long-time being exposed to mobile facilities provides people with more accesses to personalized recommendation of mobile devices. Personalized recommendation that analyzed by big data has positive effect on consumers enjoyment that promotes impulsive purchase.[9]

To be concluded, things will not quickly return to normal as we expected after COVID-19.[10] The lifestyle of people are influenced and consumers are changed to be more negative and sensitive towards the future.

\section{COUNTER-STRATEGY OF HAIDILLAO HOT POT}

\subsection{Raise the Price and Reduce the staff}

Although Haidilao has three main sources of revenue: restaurants, takeout and selling seasonings, the profits brought by restaurants is incomparable. In 2018, the income from eating-in occupies 97.18\%.[4] After the reopen in April 2020, restaurants of Haidilao in mainland China raised the price by $6 \%$. For instance, a bowl of rice costs 7 yuan, a half portion of blood goes up from 16 yuan 
to 23 yuan, and a half portion of potato chips costs 13 yuan. Such behavior causes the dissatisfaction of the public and is ceased by April 10th in 2020.

Except for the seeming rise in price, there are also invisible measures which can be reflected in Haidilao' $\mathrm{s}$ financial statement for the first half of 2020. In the first half of 2020, the unit price of customers in Haidilao mainland stores has achieved positive growth, reaching 118.1 yuan in big cities, 107.4 yuan in second-tier cities,
101.8 yuan in third-tier cities, and 191.3 yuan in areas outside the mainland. Meanwhile, on the basis of report, the per capita consumption of Haidilao is 112.8 yuan, which has an increase of $8.05 \%$ compared with 104.4 yuan in the same period last year.

To cut down the cost of labour, Haidilao reduces their employees. Based on the report released by Haidilao official, the number of employees has fallen by 10614 .

Table 3. Change in the number of Haidilao employees from 2019 to 2020.

\begin{tabular}{l|l|l}
\hline Year & 2019.12 & 2020.6 \\
\hline The number of employees & 102793 & 92179 \\
\hline The cost of employees(millions) & 7.99 & 4.07 \\
\hline
\end{tabular}

\subsection{Develop Delivery Service and Semi-finished Products}

According to Haidilao officials, the delivery service grows strongly as orders for food delivery increased, with the revenue exceeding 400 million yuan, accounting for 4.2 percent of the total revenue, up from 1.6 percent. However, due to the inconvenient characters such as the recycle of pots and the obstacles of reality like the control of communities, the contribution is still limited.

Moreover, since the launch of convenient hot pot products in 2017 brought sales revenue of 61.341 million yuan to Haidilao's subsidiary, Yi Hai International company, and convenient hot pot has also become one of Haidilao's important derivatives. During the pandemic, the sales of convenient hot pot is booming.

\section{DISCUSSION}

This paper employs STP strategy as support to analyze Haidilao hot pot. STP, which is abbreviated from segmenting market, targeting market and positioning, is defined by Philip Kotler as the core of modern marketing.[11]

Nowadays, consumers are much more complicated and various than before, which makes segmenting market necessary for companies.Furthermore, Shenghong, Ye innovatively explains that to fit personalized tendency of modern market, segmenting market is to divide and clarify the market based on different demands of customers, the competitiveness of company and the analysis of competitors. Then, targeting market, on the basis of clarifying the competitive core of company, is to choose specific customers that companies intend to serve for and to reflect differences with competitors at the same time. Also, the differences need to be realized by consumers.[12] Moreover, according to Philip.K, positioning is to impress customers with a series of actions such as designing products and brand.[11]

\subsection{Analysis}

Based on the STP strategy, it is obvious that customers that Haidilao segments and targets is young people who pursue new things and fashion. With the popularization of the Internet, the information people received has exploded. Only get enough heat and flow, can a brand get enough attention. By using short video platforms and social media, Haidilao win the public attention by advertising ways to eat its food and its considerate service which is not equipped by its competitors.

Although Haidilao is famous for its special and characteristic service in the market, the service is easy to be imitated. The moat of Haidilao is low rent and manageable supply-chain. The comprehensive supply chain and low rent help it save huge cost and get through the pandemic. Moreover, after reopen, Haidilao attaches great importance to the implementation of the Covid-19 pandemic prevention work like maintaining eating distance, taking the temperature of staff every day and disinfecting regularly, which caters to consumers, preference of safety and health. Meanwhile, the convenient hot pot achieves a great success during the quarantine. However, Haidilao does not catch changes in consumer psychology.

As mentioned in the former, Haidilao increases the price after reopen, which causes strong dissatisfaction among consumers. Consumers are changed to be more sensitive, especially to the price. The consumption ability of Chinese consumers has been restricted and nibbled away because of the revenue decrease caused by corporate layoffs and wage cuts during the epidemic. Meanwhile, Haidilao's original price has already been higher than its competitors, and consumers did not pay much attention to before because of its good service, but the circumstance is different due to the impact of the epidemic.[13] 


\section{CONCLUSION}

The paper researches the impact posed by Covid-19 on China's food-service industry from four perspectives: profits, supply chain, cash flow and consumer behaviors. Firstly, the profits declined because of people eating out less and the nationwide lockout. Secondly, supply chain was challenged because of the deficiency as well as imperfection of standard of industry and long-time lockout. Thirdly, the cash flow was risky because of the huge cost of operation and the difficulty to get loans. Finally, the primary manifestation of consumer behavior has become more cautious, pessimistic and sensitive because of the prediction of income decrease and unemployment, meanwhile, they preferred simple, healthy and safe foods.

Based on the analysis of influence and case study, to figure out these issues, the following countermeasures are developed.

Firstly, companies should expand the scope of production and present special offers, which satisfies the change of consumer demand. Secondly, companies should take advantage of online platform and develop delivery service. As the Internet develops rapidly in China, food-service companies should grab the chance by finding their position, customers and marketing strategy. Thirdly, companies should build comprehensive supplychain system by using big data technology to realize information sharing. The research can be beneficial to the recovery and development of catering industry.

\section{AUTHORS' CONTRIBUTIONS}

This paper is independently completed by the author.

\section{ACKNOWLEDGMENT}

Thanks for the support from teachers and teaching assistant whose brilliant marketing courses enlighten me.

\section{REFERENCES}

[1] China Cuisine Association releases the report on the impact of COVID-19 epidemic on China's catering industry in 2020 [J]. Food of China, 2020(04): 8087.

[2] Liang Peng, Xing Lixia. Study on the impact of COVID-19 epidemic on catering industry and countermeasures [J]. Times Business, 2020(07): 812.

[3] Yu Lixia, Liu Yi, Li Yuhan. Research on the Financial Dilemma of Chinese Catering Enterprises under the COVID-19 [J]. Friends of Accounting, 2020(09): 145-148.

[4] Chen Yu. Research on the Profit Model of Haidilao [D]. Nanchang University, 2019.
[5] WANG Q. Analysis on the trend of catering development in China after COVID-19 [J]. Fortune Times, 2020(02): 238 .

[6] Yuan Xiaoling, Li Caijuan, Wang Fei. Analysis and Suggestions on the Dynamic Change of Resident Consumption under the Epidemic [J].Journal of Beijing University of Technology (Social Science Edition), 2020,20(05): 31-39.

[7] Li Liuying, Wu Jiateng.Impact of COVID-19 epidemic on consumer behavior and its formation mechanism [J]. Consumer Economy,2020,36(3): 1926.

[8] Samuel Lins, Sibele Aquino,Development and initial psychometric properties of a panic buying scale during COVID-19 pandemic, Heliyon, Vol 6.

[9] Zhang, W., Leng, X. \& Liu, S. Research on mobile impulse purchase intention in the perspective of system users during COVID-19. Pers Ubiquit Comput(2020).

[10] Fenwick, M., McCahery, J.A. \& Vermeulen, E.P.M. Will the World Ever Be the Same After COVID-19? Two Lessons from the First Global Crisis of a Digital Age. Eur Bus Org Law Rev (2020).

[11] Philip Kotler. Marketing management[M]. Beijing:China Renmin University Press, 2001, 45127.

[12] Ye Shanghong. On the construction of STP marketing strategy model [J]. Journal of Guangdong Business College, 2004(03): 39-41+50.

[13] Zhang Haowei. Research on Business Ethical Issues under COVID-19 Epidemic -- Comparison between Price Increase of Haidilao and High-profile Price Reduction of McDonald's[J]. Liaoning Economy, 2020(07): 36-37. 